\title{
Farnesol-induced growth inhibition in Saccharomyces cerevisiae by a cell cycle mechanism
}

\author{
Kiyotaka Machida, ${ }^{1}$ Toshio Tanaka, ${ }^{1}$ Yoshihisa Yano, $^{2}$ Shuzo Otani ${ }^{2}$ \\ and Makoto Taniguchi ${ }^{1}$
}

\author{
Author for correspondence: Toshio Tanaka. Tel: +816605 3163. Fax: +81 66053164 . \\ e-mail: tanakato@sci.osaka-cu.ac.jp
}

1 Department of Bio- and
Geoscience, Graduate
School of Science, Osaka
City University, 3-3-138
Sugimoto, Sumiyoshi-ku,
Osaka 558-8585, Japan
2 Second Department of
Biochemistry, Medical
School, Osaka City
University, 1-4-54 Asahi-
machi, Osaka 545, Japan

\section{INTRODUCTION}

Isoprenoids are involved in the biosynthetic pathways of sterols, dolicohols, haems and ubiquinones in a variety of organisms (Goldstein \& Brown, 1990), as well as those for isoprenoid membrane lipids in Archaea (Zhang \& Poulter, 1993). Isoprenoids play another essential role in post-translational modification of oncogenic RAS proteins and other $G$ proteins in which farnesyl and geranylgeranyl moieties function in determining their inner-membrane location and activation for signal transduction (Glomset et al., 1990). Farnesyl pyrophosphate and geranylgeranyl pyrophosphate are commonly found as ine intermediates in the sequential reactions for isoprenoid biosynthesis and are also used as the substrates in other reactions for protein prenyl-

Abbreviations: DAG, 1,2-diacylglycerol; $\mathrm{FOH}$, trans,trans-farnesol; GGOH, all-trans-geranylgeraniol; GOH, trans-geraniol; OAG; 1-oleoyl-2acetyl-sn-glycerol; PC, phosphatidylcholine; PKC, protein kinase $C$. ation. Farnesol $(\mathrm{FOH})$ and geranylgeraniol (GGOH) can thus be endogenously generated, possibly by enzymic dephosphorylation of the corresponding pyrophosphate esters in mammalian cells (Bansal \& Vaidya, 1994). Unexpectedly, exogenous FOH and GGOH were found to inhibit the proliferation of human acute leukaemia CEM-C1 cells and human promyelocytic HL60 cells, respectively, thereby inducing apoptotic cell death as reflected in the predicted DNA fragmentation pattern (Melnykovych et al., 1992; Haug et al., 1994; Voziyan et al., 1995; Ohizumi et al., 1995).

Phosphatidylinositol-type signalling is widely conserved among eukaryotic cells, including yeasts, to regulate cell proliferation or growth in response to the cellular diacylglycerol (DAG) level. Protein kinase C (PKC)dependent signal transduction has been studied with the aid of a membrane-permeable DAG analogue, 1-oleoyl2-acetyl-sn-glycerol (OAG) which can activate the enzyme under physiological conditions. FOH-treated mammalian cells were protected against apoptotic cell 
death by the coaddition of DAG analogue, with a parallel loss of DNA fragmentation (Haug et al., 1994; Voziyan et al., 1995). This suggests that FOH induces apoptosis of mammalian cells possibly by reducing the intracellular level of DAG so as to cause inactivation of PKC.

In a previous study we found an inhibitory effect of a long-chain alkyl derivative of UMP on the pheromoneinduced sexual agglutination of Saccharomyces cerevisiae, an initial step of the mating process between cells of $a$ and $\alpha$ mating type (Machida et al., 1997). The presence of the UMP derivative allowed both $a$ and $\alpha$ haploid cells to grow normally in a vegetative manner, indicating a non-cytotoxic effect as a cause of the above biological event. Although the exogenous addition of FOH inhibited agglutination more effectively than the UMP derivative, this inhibition was accompanied by a potent growth-inhibitory effect. The yeast cell growth was arrested at a lower concentration of FOH than can affect the fluidity of the cytoplasmic membrane due to its lipophilic property. These results suggested a correlation between $\mathrm{FOH}$-induced growth inhibition in yeast cells and $\mathrm{FOH}$-mediated apoptosis in mammalian cells. In the present study, we characterize the $\mathrm{FOH}$-induced growth inhibition in S. cerevisiae in terms of its relation to a phosphatidylinositol-type signalling function in cell cycle regulation.

\section{METHODS}

Strains and media. Unless stated otherwise, $S$. cerevisiae $\mathrm{X} 2180-1 \mathrm{~A}$ (MAT $\alpha$ ) (Machida et al., 1997) was used throughout. Some other yeast strains, filamentous fungi and bacteria (see Results and Discussion) were also used for $\mathrm{FOH}$ antimicrobial activity assays by the serial broth dilution method as described previously (Akeda et al., 1995). Growth properties of $S$. cerevisiae X2180-1A cells were examined at $30{ }^{\circ} \mathrm{C}$ in YPD medium, which contained $1 \%$ yeast extract, $2 \%$ polypeptone and $2 \%$ glucose.

Measurements of cell growth. Unless otherwise stated, yeast cells were grown overnight in YPD medium at $30^{\circ} \mathrm{C}$ with vigorous shaking and were inoculated into freshly prepared medium to give an initial cell density of approximately $10^{6}$ cells $\mathrm{ml}^{-1}$. Portions were withdrawn at intervals to measure the cell density $\left(O D_{610}\right)$ and the number of c.f.u. by plating appropriately diluted samples on YPD agar and incubating at $30^{\circ} \mathrm{C}$. A yeast cell suspension of $10^{6}$ cells $\mathrm{ml}^{-1}$ gave an $\mathrm{OD}_{610}$ value of approximately $0 \cdot 1$. The relative cell growth was calculated using $\mathrm{OD}_{610}$ values as previously described (Machida et al., 1997). The proportions of budded cells to total cells were measured by counting 600 cells per sample under an Olympus BX 50 microscope, as described by Smith et al. (1995).

Lipid extraction. Yeast cells were inoculated into YPD medium at an initial cell density of $10^{7}$ cells $\mathrm{ml}^{-1}$ and grown at $30^{\circ} \mathrm{C}$ with or without addition of $\mathrm{FOH}$. At various times, $30 \mathrm{ml}$ portions were withdrawn and cells were collected by centrifugation. Cell pellets were then suspended in $1.0 \mathrm{ml} 0.2 \mathrm{M} \mathrm{KCl}$ containing $5 \mathrm{mM}$ EDTA, and the lipids extracted by a modification of the method of Bligh \& Dyer (1959), as follows. Cells were disrupted by repeated vortexing with $500 \mathrm{mg}$ glass beads ( $500 \mu \mathrm{m}$ diameter) for five $30 \mathrm{~s}$ periods. The supernatant obtained after centrifugation was then mixed with $3.75 \mathrm{ml}$ chloroform/methanol $(1: 2, \mathrm{v} / \mathrm{v})$. After extensively stirring the monophase, $1.25 \mathrm{ml}$ chloroform and $1.25 \mathrm{ml} 0.2 \mathrm{M} \mathrm{KCl}$ containing $5 \mathrm{mM}$ EDTA were added to break the phase. The resulting two phases were separated by centrifugation at $5000 \mathrm{~g}$ for $2 \mathrm{~min}$. The lower chloroform phase was evaporated under $\mathrm{N}_{2}$ and the pellet was stored in a solution of benzene/ hexane $(1: 1, \mathrm{v} / \mathrm{v})$ at $-20{ }^{\circ} \mathrm{C}$ until use.

Quantitative assay of DAG. DAG contents in the lipid fractions were measured by a radioenzymic assay employing DAG kinase, which quantitatively converts DAG to the corresponding $\left[{ }^{32} \mathrm{P}\right]$ phosphatidic acid in the presence of $[\gamma-$ ${ }^{32}$ P]ATP (Preiss et al., 1986). A DAG assay kit (Amersham) was used. $\left[{ }^{32} \mathrm{P}\right]$ Phosphatidic acid formed in the reaction was measured by a BAS 1000 bio-imaging analyser (Fuji Film Co.) after separation by thin-layer chromatography using a silica gel plate (Merck 60) and a solvent of chloroform/ methanol/acetate $(65: 15: 5$, by vol.).

RNA isolation and differential display analysis. The yeast cells were grown at $30^{\circ} \mathrm{C}$ for $30 \mathrm{~min}$ with or without $\mathrm{FOH}$ and collected as described in the section on lipid extraction. Cells were then disrupted by ten $30 \mathrm{~s}$ periods of vortexing at $4{ }^{\circ} \mathrm{C}$, and total RNA was isolated by a modified guanidine thiocyanate method using a Quick Prep total RNA extraction kit (Pharmacia Biotech).Total RNA fractions thus obtained were employed for the following differential display analysis using a differential display assay kit (Display Systems) after treatment with RNase-free DNase. This assay kit provides 24 upstream primers and 9 downstream primers and we employed a total of $24 \times 9$ PCR reactions using RNA fractions isolated from yeast cells with or without FOH treatment. The first-strand cDNA was synthesized in $30 \mu \mathrm{l}$ RT-PCR buffer (Takara, Japan) containing total RNA $(6-9 \mu \mathrm{g}), 20 \mu \mathrm{M}$ of each dNTP, $2 \mathrm{mM} \mathrm{MgCl}_{2}, 30$ units RNase inhibitor (Takara), $2.5 \mu \mathrm{M}$ of the arbitrary downstream primer and 7.5 units AMV reverse transcriptase $\mathrm{XL}$ (Takara) at $55^{\circ} \mathrm{C}$ for $30 \mathrm{~min}$ followed by the annealing at $30^{\circ} \mathrm{C}$ for $10 \mathrm{~min}$. The mixture was heated at $95^{\circ} \mathrm{C}$ for $5 \mathrm{~min}$ to inactivate of reverse transcriptase, diluted with $80 \mu \mathrm{l}$ TE buffer $(10 \mathrm{mM}$ Tris $/ \mathrm{HCl}$ $\mathrm{pH} 8 \cdot 0,1 \mathrm{mM}$ EDTA) and stored at $-80^{\circ} \mathrm{C}$ until use. The reaction mixture $(20 \mu \mathrm{l})$ for PCR contained $1 \mu \mathrm{l} \mathrm{cDNA}$ solution prepared as above, $0.5 \mu \mathrm{M}$ of the arbitrary upstream primer, $2.5 \mu \mathrm{M}$ of the arbitrary downstream primer, $2 \mu \mathrm{M}$ of each dNTP, $3 \mathrm{mM} \mathrm{MgCl}_{2},\left[\alpha^{-}{ }^{33} \mathrm{P}\right] \mathrm{dATP}\left(1.85 \mathrm{MBq} \mathrm{ml}^{-1}\right)$ and 10 units Taq DNA polymerase in the PCR buffer (Takara). The mixture was subjected to 30 cycles $\left(95^{\circ} \mathrm{C}\right.$ for $30 \mathrm{~s}$ for denaturation, $37^{\circ} \mathrm{C}$ for $1 \mathrm{~min}$ for low-stringency annealing of arbitrary primer, and $72^{\circ} \mathrm{C}$ for $1 \mathrm{~min}$ for second-strand extension), followed by three cycles $\left(95^{\circ} \mathrm{C}\right.$ for $30 \mathrm{~s}, 46^{\circ} \mathrm{C}$ for $1 \mathrm{~min}$ and $72{ }^{\circ} \mathrm{C}$ for $1 \mathrm{~min}$ ), three cycles $\left(95^{\circ} \mathrm{C}\right.$ for $30 \mathrm{~s}, 43^{\circ} \mathrm{C}$ for $1 \mathrm{~min}$ and $72^{\circ} \mathrm{C}$ for $\left.1 \mathrm{~min}\right)$, another three cycles $\left(95^{\circ} \mathrm{C}\right.$ for $30 \mathrm{~s}, 40^{\circ} \mathrm{C}$ for $1 \mathrm{~min}$ and $72^{\circ} \mathrm{C}$ for $1 \mathrm{~min}$ ) and an additional final extension at $72{ }^{\circ} \mathrm{C}$ for $5 \mathrm{~min}$. The amplified cDNAs $(10 \mu$ l) were separated on a $6 \%$ polyacrylamide gel in $0.375 \mathrm{M}$ Tris $/ \mathrm{HCl}(\mathrm{pH} 8.9)$ using $0.25 \mathrm{M}$ Tris $/ 0 \cdot 192 \mathrm{M}$ glycine running buffer as described by Ito et al. (1993). Band patterns were visualized by autoradiography with a BAS 2000 bio-imaging analyser (Fuji Film Co.). The overall step was run in duplicate and reproduced bands were used in the next step.

Reamplification, cloning, sequencing of DNA fragments, and Northern analysis. Gel pieces containing the bands of interest were excised from the gel using a blade, and added directly into $50 \mu \mathrm{l} \mathrm{PCR}$ mixture containing $0.2 \mu \mathrm{M}$ upstream primer, $0 \cdot 2 \mu \mathrm{M}$ downstream primer, $2 \mathrm{mM} \mathrm{MgCl}_{2}, 50 \mu \mathrm{M}$ of each dNTP, and 2.5 units Taq DNA polymerase in the PCR buffer (Takara). The corresponding DNA fragments were reamplified with the same condition as for the differential display PCR 
assay. Upstream primers and downstream primers which could reamplify each band were as follows: band (a), upstream primer 7 , downstream primer 3 ; band (b), upstream primer 14, downstream primer 3; band (c), upstream primer 19, downstream primer 4 ; band (d), upstream primer 15 , downstream primer 6; band (e), upstream primer 7, downstream primer 4. Reamplified DNA fragments were then cloned into the pCR-Script $\operatorname{AmpSK}(+)$ cloning vector (Strategene). Among the transformants obtained, clones bearing the bands of interest were identified as described by Adati et al. (1996).

Following isolation by the alkaline-SDS method and subsequent polyethylene glycol precipitation (Sambrook et al., 1989), cloned DNA fragments were sequenced by the dideoxy chain-termination method (Sanger et al., 1977) using an ABI Prism 373 Dye Terminator Cycle Sequencing Core kit (Applied Biosystems). Sequence data were subjected to homology searching at the nucleotide level using the BLAST program on the $S$. cerevisiae Genome Database at Stanford. For Northern analysis, total RNA fractions were again isolated from yeast cells grown at $30^{\circ} \mathrm{C}$ for $30 \mathrm{~min}$ with or without $100 \mu \mathrm{M} \mathrm{FOH}$ as described above. Total RNAs $(10 \mu \mathrm{g})$ were resolved on a $1.0 \%$ agarose $/ 2.2 \mathrm{M}$ formaldehyde gel, blotted onto a Hybond-N membrane filter (Amersham) and then hybridized with $\alpha-{ }^{32} \mathrm{P}$-labelled probes by the standard procedure (Sambrook et al., 1989). The ACT1 (yeast actin gene) transcript was used as an internal control for loading. In the Northern analysis, the total RNA fractions were also prepared from cells grown in YPD medium containing both $100 \mu \mathrm{M}$ FOH and $30 \mu \mathrm{M}$ OAG. DNA probes used were a $110 \mathrm{bp}$ Pst fragment for CDC9, a 230 bp PstI fragment for HAT2, and a 520 bp Styl fragment for ACT1, which were isolated with the QiaQuick Gel Extraction kit (Qiagen) after purification by gel electrophoresis. Band patterns were visualized by autoradiography with a BAS 2000 bio-imaging analyser (Fuji Film Co.).

Chemicals. GOH (trans-geraniol), nerol (cis-GOH), linalool, squalene, FOH, farnesyl acetate and GGOH were purchased from either Aldrich or Sigma. These chemicals were kept as solutions in ethanol. Phospholipids and OAG were from Sigma and were kept as solutions in dimethylformamide. Other chemicals were of analytical reagent grade.

\section{RESULTS AND DISCUSSION}

\section{Effects of FOH and other isoprenoids on yeast cell growth and viability}

A potent antimicrobial activity of $\mathrm{FOH}$ was first observed with the follicular bacterium Propionibacterium acnes (Kubo et al., 1994) and more recently with a halophilic archaeon, Haloferax volcanii (Tachibana et al., 1996). A step of mevalonate biosynthesis was proposed to be one of the $\mathrm{FOH}$-sensitive sites in $H$. volcanii. However, FOH did not show any antibacterial activity against Escherichia coli IFO 3545, Staphylococcus aureus NCTC 8530 or Bacillus subtilis IFO 3007 in our experiment using the serial broth dilution method. $\mathrm{FOH}$ was also inactive against the filamentous fungi Aspergillus niger ATCC 6275 , Penicillium chrysogenum IFO 4626 and Mucor mucedo IFO 7684. In contrast, $\mathrm{FOH}$ inhibited the growth of various yeast strains such as S. cerevisiae X2180-1A (MATa), S. cerevisiae X21801B $(M A T \alpha)$ and Schizosaccharomyces pombe IFO 0342, with minimum inhibitory concentrations less than $25 \mu \mathrm{M}$. As shown in Table 1 , the growth of $S$. cerevisiae
Table 1. Inhibitory effects of FOH and related isoprenoids on the growth of $S$. cerevisiae

Yeast cells were grown at $30^{\circ} \mathrm{C}$ for $4 \mathrm{~h}$ in YPD medium in which the initial cell density was adjusted to $10^{7} \mathrm{ml}^{-1}\left(\mathrm{OD}_{610}\right.$ approx. 1.00).

\begin{tabular}{|lcc|}
\hline Addition & $\begin{array}{c}\text { Concn } \\
(\boldsymbol{\mu} \mathbf{M})\end{array}$ & $\begin{array}{c}\text { Relative cell } \\
\text { growth }(\%)^{*}\end{array}$ \\
\hline None & - & 100 \\
GOH & 400 & 91 \\
& 200 & 98 \\
Nerol & 400 & 90 \\
& 200 & 101 \\
Linalool & 400 & 101 \\
FOH & $6 \cdot 25$ & 104 \\
& $12 \cdot 5$ & 71 \\
& 25 & 2 \\
GGOH & 100 & 0 \\
Farnesyl acetate & 400 & 98 \\
& 400 & 83 \\
Squalene & 200 & 96 \\
\hline
\end{tabular}

*The $\mathrm{OD}_{610}$ value corresponding to $100 \%$ was $4 \cdot 36 \pm 0 \cdot 8$. All measurements were done in triplicate and the mean values are given.

X2180-1A was almost completely inhibited in shaking culture with $25 \mu \mathrm{M}$ FOH. GOH, nerol, linalool, squalene and GGOH did not show apparent growthinhibitory effects even at $400 \mu \mathrm{M}$. Farnesyl acetate inhibited yeast cell growth slightly at $400 \mu \mathrm{M}$. Isoprenoid alcohols may exhibit different biological activities depending on the tested organism, although the corresponding pyrophosphate esters are commonly involved in the initial step of their isoprenoid metabolism (Goldstein \& Brown, 1990; Zhang \& Poulter, 1993). $\mathrm{GOH}$ was evaluated as a lipophilic agent which can increase cytoplasmic membrane fluidity, thereby inhibiting the growth of Candida albicans and S. cerevisiae at high concentrations around $3 \mathrm{mM}$ (Bard et al., 1988). $\mathrm{GOH}$ could enhance potassium leakage from whole cells of $S$. cerevisiae under the above conditions. $\mathrm{FOH}$ was likely to exhibit a different type of yeastcidal activity since the yeast cells significantly lost the ability to form colonies on YPD agar at $48 \mathrm{~h}$ cultivation when they had been exposed to only $25 \mu \mathrm{M}$ FOH for $15 \mathrm{~min}$ or less (Fig. 1a). However, the FOH-treated cells still kept the ability to divide so that they could form visible colonies after $96 \mathrm{~h}$ cultivation on the agar plate. As shown in Fig. 1(b), FOH-treated cells were all viable even after $6 \mathrm{~h}$ incubation in the medium with $25 \mu \mathrm{M}$ $\mathrm{FOH}$ as judged from the fact that the numbers of c.f.u. were comparable to those in the original inoculum. This means that FOH-treated cells were prevented from normal cell division for an extremely extended period.

Microscopic observation revealed a marked increase in the proportion of unbudded cells in the population at 


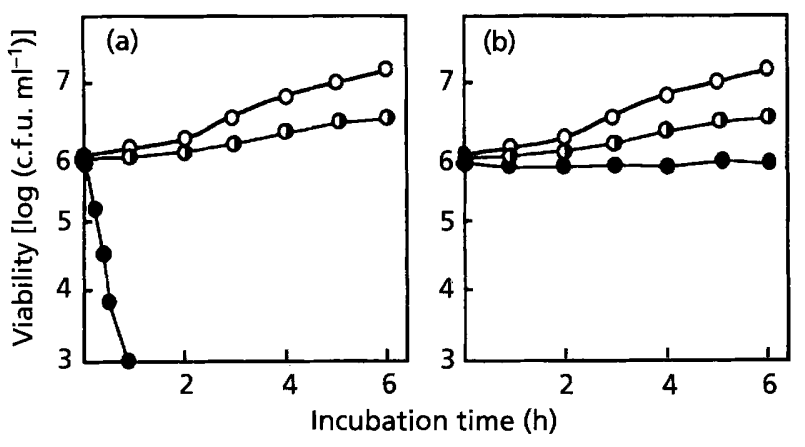

Fig. 1. Growth-inhibitory effects of $\mathrm{FOH}$ on cells of $S$. cerevisiae. Cells were grown in YPD medium containing FOH at $0(0), 12.5(0)$ or $25 \mu \mathrm{M}(0)$. Cell viability was expressed as the number of c.f.u., counted after $48 \mathrm{~h}$ (a) and $96 \mathrm{~h}$ (b) cultivation on YPD agar.

Table 2. Transition of budded to unbudded phase of $\mathrm{FOH}$-treated S. cerevisiae cells

\begin{tabular}{|lcc|}
\hline FOH $(\boldsymbol{\mu M})$ & $\begin{array}{c}\text { Incubation } \\
\text { time }(\mathrm{h})\end{array}$ & $\begin{array}{c}\text { Proportion of } \\
\text { budded cells }(\%)^{*}\end{array}$ \\
\hline 0 & 2 & $69 \pm 7$ \\
& 4 & $76 \pm 6$ \\
$12 \cdot 5$ & 2 & $68 \pm 8$ \\
25 & 4 & $73 \pm 5$ \\
& 2 & $26 \pm 4$ \\
& 4 & $28 \pm 7$ \\
\hline
\end{tabular}

"Values are means $\pm S D$ in triplicate assays.

both 2 and $4 \mathrm{~h}$ incubation with $25 \mu \mathrm{M}$ FOH (Table 2). About $70 \%$ of the cells were budded in the medium without $\mathrm{FOH}$. FOH-induced growth inhibition of yeast cells was characterized as a static but a potent growtharresting effect, as is the case with $\mathrm{Li}^{+}$-induced cell cycle arrest in G1 of S. cerevisiae cells, which was assessed by a similar transition from budded to unbudded phase (Smith et al., 1995). Fig. 1 also shows a remarkable difference between the response of cells in the medium with 12.5 and $25 \mu \mathrm{M}$ FOH. A similar result has been reported for the growth-inhibitory effect of $\mathrm{FOH}$ on human acute leukaemia CEM-1 cells (Haug et al., 1994). The mammalian cells were mostly viable $(84.0 \%)$ in the medium with $25 \mu \mathrm{M}$ FOH but drastically lost viability to $0.6 \%$ of the original level when exposed to $30 \mu \mathrm{M} \mathrm{FOH}$ It remains to be solved how such a modest change in FOH concentration could evoke such a strong response.

\section{Time course of the change in intracellular DAG level in FOH-treated cells}

In experiments with a human acute leukaemia cell line, FOH-induced apoptotic cell death was accompanied by a significant decrease in the cellular DAG level (Voziyan et al., 1995). We measured the intracellular level of

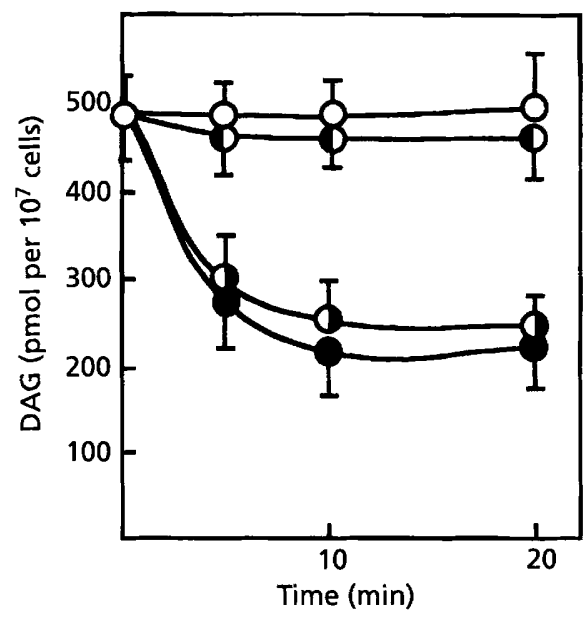

Fig. 2. Time course of the change in DAG level during incubation with FOH. Cells were grown in YPD medium containing $\mathrm{FOH}$ at $0(\mathrm{O}), 12.5(\mathrm{O}), 25(\mathrm{O})$ or $100 \mu \mathrm{M}(\mathrm{O})$. Values are means \pm SD of triplicate assays.

DAG, which also functions as a modulator of phosphatidylinositol-type signalling in yeast (Ogita et al., 1990), in the presence or absence of added FOH. As shown in Fig. 2, the intracellular DAG level was drastically decreased by $5 \mathrm{~min}$ incubation with $25 \mu \mathrm{M} \mathrm{FOH}$, correlating with the failure in cell division or budding of the cells thus treated. DAG was maximally decreased to $40-50 \%$ of the original level at $10 \mathrm{~min}$ of incubation in the medium containing $\mathrm{FOH}$ at $25 \mu \mathrm{M}$ or higher. In $\alpha$ pheromone-treated cells of $S$. cerevisiae, the cellular content of DAG was similarly reduced to the lowest level, around $150 \mathrm{pmol}$ per $10^{7}$ cells, along with a drastic decrease in the budded cell population (Marini et al., 1996). DAG was again increased up to 300 pmol per $10^{7}$ cells in the following synchronous recovery from the mating-pheromone-induced cell cycle arrest. It is unlikely that $\mathrm{FOH}$-treated cells could not reinitiate the cell cycle upon the following removal of exogenous $\mathrm{FOH}$ (see Fig. 1). This would require a long-lasting $\mathrm{FOH}$ induced event (as discussed in the following section) since $\mathrm{FOH}$ itself can be metabolized into the corresponding isoprenoid compounds via the formation of farnesyl pyrophosphate (Crick et al., 1997).

\section{Protective effects of OAG on FOH-induced growth inhibition}

In mammalian cells, the $\mathrm{FOH}$-induced inhibition of cell proliferation could be restored with either exogenously added phosphatidycholine (PC) or OAG, a physiological activator of PKC (Melnykovych et al., 1992). OAG is also known to activate PKC from $S$. cerevisiae cells as effectively as the enzyme from mammalian cells (Ogita et al., 1990). As shown in Fig. 3, the exogenous addition of PC was effective in preventing the growth-inhibitory effect of $\mathrm{FOH}$; a weak protective effect was observed with phosphatidylserine but no protective effect with phosphatidylinositol, phosphatidylethanolamine or 


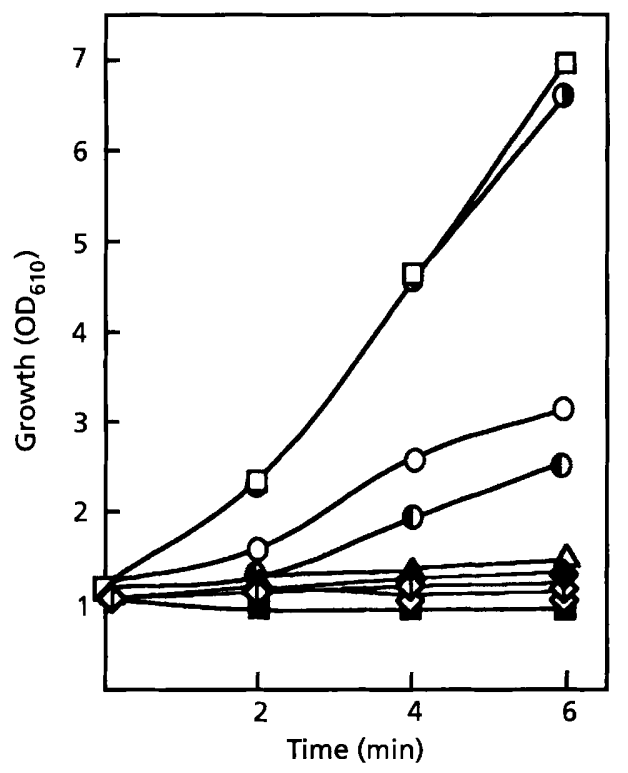

Fig. 3. Protective effects of phospholipids and OAG on FOHinduced growth inhibition of 5 . cerevisiae. Cells were grown in YPD medium with ( $\square$ ) or without $(\square) 25 \mu \mathrm{M}$ FOH. Cells were also grown in YPD medium containing $25 \mu \mathrm{M} \mathrm{FOH}$ and $100 \mu \mathrm{M}$ $\mathrm{PC}(\mathrm{O}), 25 \mu \mathrm{M}$ FOH and $100 \mu \mathrm{M}$ phosphatidylserine $(\triangle), 25 \mu \mathrm{M}$ FOH and $10 \mu \mathrm{M}$ OAG (O), $25 \mu \mathrm{M}$ FOH and $30 \mu \mathrm{M}$ OAG (O). $25 \mu \mathrm{M}$ FOH and $100 \mu \mathrm{M}$ phosphtidylinositol $(\diamond), 25 \mu \mathrm{M}$ FOH and $100 \mu \mathrm{M}$ phosphatidylethanolamine $(\bowtie)$, and $25 \mu \mathrm{M}$ FOH and $100 \mu \mathrm{M}$ phosphatidic acid $(\bullet)$.

Table 3. Time-dependent loss of growth recovery in $\mathrm{FOH}$-induced-growth-inhibition of S. cerevisiae cells

In control assays, cells were grown in YPD medium with or without $25 \mu \mathrm{M} \mathrm{FOH}$ at $30^{\circ} \mathrm{C}$ for $4 \mathrm{~h}$. Cells were also pretreated with $25 \mu \mathrm{M} \mathrm{FOH}$ at $30^{\circ} \mathrm{C}$ for the indicated periods, and then grown for a further $4 \mathrm{~h}$ following the addition of $30 \mu \mathrm{M} \mathrm{OAG}$.

\begin{tabular}{|lccc|}
\hline Addition & $\begin{array}{c}\text { Period of } \\
\text { pretreatment } \\
(\text { min })\end{array}$ & $\begin{array}{c}\text { Growth } \\
\left(\mathrm{OD}_{610}\right)\end{array}$ & $\begin{array}{c}\text { Relative cell } \\
\text { growth }(\%)^{*}\end{array}$ \\
\hline None & - & $4 \cdot 60 \pm 0 \cdot 23$ & 100 \\
FOH & - & $1 \cdot 03 \pm 0 \cdot 15$ & 1 \\
FOH/OAG & 0 & $4 \cdot 67 \pm 0 \cdot 16$ & 100 \\
& 5 & $4 \cdot 26 \pm 0 \cdot 18$ & 91 \\
& 10 & $1 \cdot 82 \pm 0 \cdot 21$ & 23 \\
& 20 & $1 \cdot 09 \pm 0 \cdot 21$ & 3 \\
\hline
\end{tabular}

*Initial $\mathrm{OD}_{610}$ values were adjusted to about $1 \cdot 00$. Values are means $\pm S D$ in triplicate assays.

phosphatidic acid. The yeast cell growth was more effectively restored with OAG than PC, which can give DAG as a result of phospholipase action (Melnykovych et al., 1992). These findings suggested that $\mathrm{FOH}$ arrested the yeast cell growth by interfering with a phosphatidylinositol-type signalling.

FOH-treated cells seemed to reinitiate growth as soon as OAG was added to the medium. From this we might assume that the yeast cell growth was only statically repressed due to a nutritional requirement for this neutral lipid. Cells were preincubated in YPD medium with $\mathrm{FOH}$ and washed with PBS. FOH-treated cells were then suspended at a density of $10^{7}$ cells $\mathrm{ml}^{-1}$ in freshly prepared YPD medium containing $30 \mu \mathrm{M}$ OAG and grown for another $4 \mathrm{~h}$. As shown in Table 3, OAG could protect the $\mathrm{FOH}$-induced growth inhibition only when it was added after $5 \mathrm{~min}$ of $\mathrm{FOH}$ pretreatment. The turbidimetric assay found no sign of cell growth initiation following addition of OAG after cells had been pretreated with $\mathrm{FOH}$ for at least $20 \mathrm{~min}$. We believe that the failure in cell growth recovery was not caused by an induction of $\mathrm{FOH}$ on a nutritional requirement for DAG but suggested a signallingmediated cell cycle arrest in $\mathrm{FOH}$-pretreated cells.

\section{Differential display analysis of gene expression under $\mathrm{FOH}$-induced growth inhibition}

We employed the differential display technique to identify the genes differentially expressed in response to the FOH treatment. As shown in Fig. 4, each mixture of arbitrary primers gave a unique fingerprint composed of various distinct bands. One of these bands (band e) exhibited an increasing expression pattern with $\mathrm{FOH}$ whereas the other four bands ( $a, b, c, d)$ showed decreasing expression patterns in both the duplicate analyses. These five bands were subjected to the following analysis to identify a genetic event with closer relation to the $\mathrm{FOH}$ treatment (although clearly these bands represented a limited population of the genes differentially expressed with or without $\mathrm{FOH}$ ). After purification of these five bands, reamplification and cloning into the plasmid vectors, each cDNA insert was sequenced by the dideoxy chain-termination method. Comparison of their partial nucleotide sequences with the genome sequence of $S$. cerevisiae revealed the cDNA sequences to be identical to the coding regions of $C D C 9$ (a), HAT2 (b), YMR116C (c), YMR226C (d) or PDR5 (e).

YMR116C is a hypothetical ORF with similarity to the G-protein $\beta$ subunit family containing seven Trp-Asp domains. YMR226C is also a hypothetical ORF which has a high homology to the mammalian $\beta$-oestradiol dehydrogenase gene. The biological significance of downregulation of these hypothetical ORFs is unknown. PDR5, the only gene identified with upregulation, is one of many multidrug-resistance genes in yeast. Expression of this gene can be stimulated by various environmental factors such as heat shock, cycloheximide (Miyahara et al., 1996a) and metal ions (Miyahara et al., 1996b). PDR 5 could be upregulated simply to export FOH out of the cell as a toxic drug. However, PDR5 expression was decreased to the normal level when OAG was added 


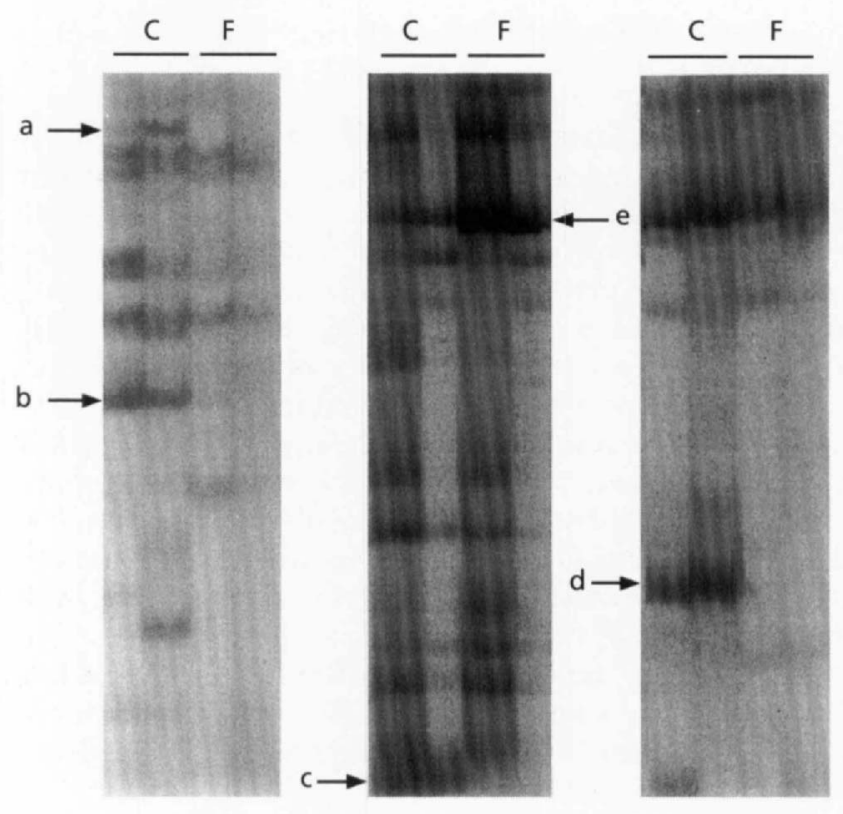

(a)

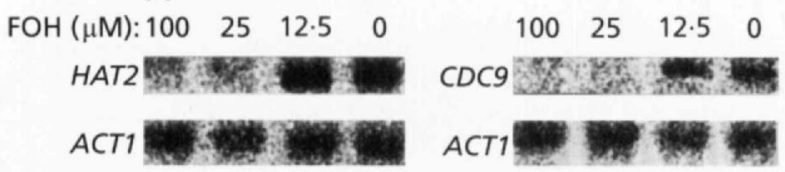

(b)

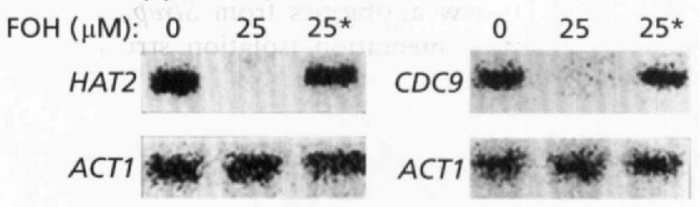

Fig. 5. Effects of FOH on CDC9 and HAT2 mRNA levels in the absence (a) and presence (b) of OAG. Cells were treated in YPD medium containing $\mathrm{FOH}$ at the indicated concentrations; the asterisks $\left(^{*}\right)$ in (b) indicate that cells were treated with $25 \mu \mathrm{M}$ $\mathrm{FOH}$ and $30 \mu \mathrm{M}$ OAG. Each RNA sample was analysed by Northern blotting as described in Methods. The blots were probed with radiolabelled CDC9 CDNA and HAT2 CDNA in addition to $A C T 1$ CDNA to demonstrate equivalent loading of samples.

Fig. 4. Differential display of CDNAs from yeast cells grown with (F) or without (C) $100 \mu \mathrm{M} \mathrm{FOH}$. Each cDNA was subjected to differential display analysis using different random primers as described in Methods. Because yeast transcripts are fewer than those of mammalian cells, the PCR reaction was carrried out using two different upstream primers and one downstream primer in order to increase the number of differentially expressed transcripts in one reaction. In the PCR mixture loaded in the left panel, upstream primers 7 ( $5^{\prime}$ GATCATGGTC $3^{\prime}$ ) and 14 (5' GGAACCAATC $\left.3^{\prime}\right)$, and downstream primer 3 (5' T 11 AG $\left.3^{\prime}\right)$ were used. In the PCR mixture loaded in the middle panel, upstream primers 7 and 19 (5' TACAACGAGG $\left.3^{\prime}\right)$, and downstream primer $4\left(5^{\prime} \mathrm{T}_{11} C A 3^{\prime}\right)$ were used. In the PCR mixture loaded in the right panel, upstream primers $15\left(5^{\prime}\right.$ GATCAATCGC $\left.3^{\prime}\right)$ and 19 , and downstream primer $6\left(5^{\prime} \mathrm{T}_{11} \mathrm{CG}\right.$ $\left.3^{\prime}\right)$ were used. Following duplicate electrophoresis on nondenaturing polyacrylamide gel, the fingerprints were visualized by autoradiography with a BAS 2000 bio-imaging analyser. The letters (a) to (e) denote CDNA fragments representing differentially expressed transcripts.

to the medium (data not shown), suggesting the involvement of signal transduction in regulation of expression. CDC9 encodes a protein with DNA ligase activity. Downregulation of this gene can cause a disorder in DNA replication and thus results in cell cycle arrest at the RAD9 checkpoint in response to DNA damage (Tomkinson et al., 1992). HAT2 encodes a protein required for high-affinity binding of acetyltransferase to histone H4 (Parthun et al., 1996; Wade et al., 1997). In eukaryotic cells, histone must be newly synthesized and acetylated in the cytoplasm during DNA replication so that acetylated products enter the nucleus for deposition onto the newly replicated DNA. Downregulation of HAT2 should also cause a disorder in DNA replication because of a decrease in the cytoplasmic level of Hat2p.

We focussed on CDC9 and HAT2 because the expression of these genes is inevitable in the cell cycle

progression and thus may be closely related to $\mathrm{FOH}$ induced growth inhibition. The expression patterns of these two cell cycle genes were examined by Northern blot analysis. As shown in Fig. 5(a), mRNA levels of CDC9 and HAT2 were significantly decreased in cells treated with $25 \mu \mathrm{M} \mathrm{FOH}$ but not in those treated with $12.5 \mu \mathrm{M} \mathrm{FOH}$. Although we used $100 \mu \mathrm{M} \mathrm{FOH}$ for differential display analysis, $25 \mu \mathrm{M} \mathrm{FOH}$ was sufficient to decrease the mRNA levels of CDC9 and HAT2, this being in agreement with the concentration of $\mathrm{FOH}$ critical for growth arrest and loss of DAG. Downregulation of CDC9 and HAT2 expression was effectively cancelled when cells were grown in medium supplemented with OAG (Fig. 5b). These results strongly support the idea that $\mathrm{FOH}$ repressed expression of CDC9 and HAT2 by reducing the intracellular level of DAG. In S. cerevisiae, PKC1 functions to activate the mitogen-activated protein (MAP) kinase cascade, a regulator of gene expression at the G1 to $S$ phase transition of the cell cycle (Madden et al., 1997). It was reported that yeast cyclin-dependent kinase encoded by CDC28 stimulated a cell-cycle-dependent hydrolysis of PC to DAG at the START control point committing the cells to enter $S$ phase and complete the next cell cycle (Marini et al., 1996). FOH-induced growth inhibition may reflect an inhibition of cell cycle transition via PKCdependent activation of the MAP kinase cascade. This was supported by the fact that yeast cell cycle was arrested in $\mathrm{G} 1$ with $\mathrm{Li}^{+}$as an inhibitor of phosphoinositide metabolism (Smith et al., 1995). Downregulation of CDC9 and HAT2 expression should reflect a cell cycle mechanism such as G1 arrest in FOHinduced growth inhibition of $S$. cerevisiae cells. We propose an interference with a phosphatidylinositoltype signalling which is involved in cell cycle progression as a cause of $\mathrm{FOH}$-induced growth inhibition in yeast cells. 


\section{REFERENCES}

Adati, N., Ito, T., Koga, C., Kito, K., Sakai, Y. \& Shiokawa, K. (1996). Differential display analysis of gene expression in developing embryos of Xenopus laevis. Biochim Biophys Acta 1262, 43-51.

Akeda, Y., Shibata, K., Ping, X., Tanaka, T. \& Taniguchi, M. (1995). AKD-2A, B, C and D, new antibiotics from Streptomyces sp. OCU-42815. Taxonomy, fermentation, isolation, structure elucidation and biological activity. J Antibiot 48, 363-368.

Bansal, V. S. \& Vaidya, S. (1994). Characterization of two distinct allyl pyrophosphatase activities from rat liver microsomes. Arch Biochem Biophys 315, 393-399.

Bard, M., Albrecht, M. R., Gupta, N., Guynn, C. J. \& Stillwell, W. (1988). Geraniol interferes with membrane functions in strains of Candida and Saccharomyces. Lipids 23, 534-538.

Bligh, E. A. \& Dyer, W. J. (1959). A rapid method of total lipid extraction and purification. Can J Biochem Physiol 37, 911-917.

Crick, D. C., Andres, D. A. \& Waechter, C. J. (1997). Novel salvage pathway utilizing farnesol and geranylgeraniol for protein isoprenylation. Biochem Biophys Res Commun 237, 483-487.

Glomset, J. A., Gelb, M. H. \& Farnsworth, C. C. (1990). Prenyl proteins in eukaryotic cells: a new type of membrane anchor. Trends Biochem Sci 15, 139-142.

Goldstein, J. L. \& Brown, M. S. (1990). Regulation of the mevalonate pathway. Nature 343, 425-430.

Haug, J. S., Goldner, C. M., Yazlovitskaya, E. M., Voziyan, P. A. \& Melnykovych, G. (1994). Directed cell killing (apoptosis) in human lymphoblastoid cells incubated in the presence of farnesol: effect of phosphatidylcholine. Biochim Biophys Acta 1223, 133-140.

Ito, T., Hohjoh, H. \& Sakai, Y. (1993). Pulsed-field polyacrylammide gel electrophoresis: basic phenomena and applications. Electrophoresis 14, 278-282.

Kubo, I., Muroi, H. \& Kubo, A. (1994). Naturally occurring antiacne agents. J Nat Prod 57, 9-17.

Machida, K., Tanaka, T., Shibata, K. \& Taniguchi, M. (1997). Inhibitory effects of nucleotide $5^{\prime}$-alkylphosphate on sexual agglutination in Saccharomyces cerevisiae. FEMS Microbiol Lett $147,17-22$.

Madden, K., Sheu, Y. J., Baetz, K., Andrews, B. \& Snyder, M. (1997). SBF cell cycle regulator as a target of the yeast PKC-MAP kinase pathway. Science 275, 1781-1784.

Marini, N. J., Meldrum, E., Buehrer, B., Hubberstey, A. V., Stone, D. E., Traynor-Kaplan, A. \& Reed, S. I. (1996). A pathway in the yeast cell division cycle linking protein kinase $\mathrm{C}$ (Pkc1) to activation of Cdc28 at START. EMBO J 15, 3040-3052.

Melnykovych, G., Haug, J. S. \& Goldner, C. M. (1992). Growth inhibition of leukemia cell line CEM-C1 by farnesol: effects of phosphatidylcholine and diacylglycerol. Biochem Biophys Res Commun 186, 543-548.
Miyahara, K., Hirata, D. \& Miyakawa, T. (1996a). yAP-1- and yAP2-mediated, heat shock-induced transcriptional activation of the multidrug resistance $\mathrm{ABC}$ transporter genes in Saccharomyces cerevisiae. Curr Genet 29, 103-105.

Miyahara, K., Mizunuma, M., Hirata, D., Tsuchiya, E. \& Miyakawa, T. (1996b). The involvement of the Saccharomyces cerevisiae multidrug resistance transporters $\operatorname{Pdr} 5 \mathrm{p}$ and Snq2p in cation resistance. FEBS Lett 399, 317-320.

Ogita, K., Miyamoto, S., Koide, H. \& 7 other authors (1990). Protein kinase $\mathrm{C}$ in Saccharomyces cerevisiae: comparison with the mammalian enzyme. Proc Natl Acad Sci USA 87, 5011-5015.

Ohizumi, H., Masuda, Y., Nakajo, S., Sakai, I., Ohsawa, S. \& Nakaya, K. (1995). Geranylgeraniol is a potent inducer of apoptosis in tumour cells. J Biochem 117, 11-13.

Parthun, M. R., Widom, J. \& Gottschling, D. E. (1996). The major cytoplasmic histone acetyltranferase in yeast : links to chromatin replication and histone metabolism. Cell 87, 85-94.

Preiss, J., Loowis, C. R., Bishop, R. W., Stein, R., Niedel, J. E. \& Bell, R. M. (1986). Quantitative measurement of sn-1,2-diacylglycerols present in platelets, hepatocytes, and ras- and sis-transformed normal rat kidney cells. J Biol Chem 616, 8597-8600.

Sambrook, J., Fritsch, E. F. \& Maniatis, T. (1989). Molecular Cloning: a Laboratory Manual, 2nd edn. Cold Spring Harbor, NY: Cold Spring Harbor Laboratory.

Sanger, F., Nicklen, S. \& Coulson, A. R. (1977). DNA sequencing with chain-terminating inhibitors. Proc Natl Acad Sci USA 74, 5463-5467.

Smith, B. E., O'Day, D. H. \& Proteau, G. A. (1995). Lithium in the mating response and cell cycle of Saccharomyces cerevisiae. Biochem Biophys Res Commun 206, 401-407.

Tachibana, A., Tanaka, T., Taniguchi, M. \& Oi, S. (1996). Evidence for farnesol-mediated isoprenoid synthesis regulation in a halophilic archaeon, Haloferax volcanii. FEBS Lett 379, 43-46.

Tomkinson, A. E., Tappe, N. J. \& Friedberg, E. C. (1992). DNA ligase I from Saccharomyces cerevisiae: physical and biochemical characterization of the CDC9 gene product. Biochemistry 31, 11762-11771.

Voziyan, P. A., Haug, J. S. \& Melnykovych, G. (1995). Mechanism of farnesol cytotoxicity: further evidence for the role of PKCdependent signal transduction in farnesol-induced apoptotic cell death. Biochem Biophys Res Commun 212, 479-486.

Wade, P. A., Pruss, D. \& Wolffe, A. P. (1997). Histone acetylation: chromatin in action. Trends Biochem Sci 22, 128-132.

Zhang, D. \& Poulter, C. D. (1993). Biosynthesis of archaebacterial ether lipids. Formation of ether linkages by prenyltransferases. $J$ Am Chem Soc 115, 1270-1277.

Received 9 July 1998; revised 12 October 1998; accepted 15 October 1998. 